Public-data File 91-21c

\title{
PRELIMINARY RESULTS OF 25 APATITE FISSION TRACK ANALYSES OF SAMPLES FROM THE GILEAD CREEK REGION, NORTH SLOPE OF ALASKA
}

\author{
by \\ P.B. O'Sullivan \\ Department of Geology \\ La Trobe University \\ Bundoora, Victoria 3083 \\ Australia \\ Alaska Division of \\ Geological and Geophysical Surveys
}

May 1991

THIS REPORT HAS NOT BEEN REVIEWED FOR TECHNICAL CONTENT (EXCEPT AS NOTED IN TEXT) OR FOR CONFORMITY TO THE EDITORLAL STANDARDS OF DGGS.

794 University Avenue, Stite 200

Fairbanks, Alaska 99709-3645 


\section{CONTENTS}

CONTENTS

$\underline{\text { Page }}$

LOCALITY MAP

INTRODUCTION 2

TECHNIQUES

SAMPLE RESULTS 4

PRELIMINARY INTERPRETATIONS

$\begin{array}{ll}\text { REFERENCES } & 10\end{array}$

GRAIN AGE DATA FROM GILEAD CREEK REGION 12

CONFINED TRACK LENGTH DISTRUBUTIONS 37

\section{LOCALITY MAP}
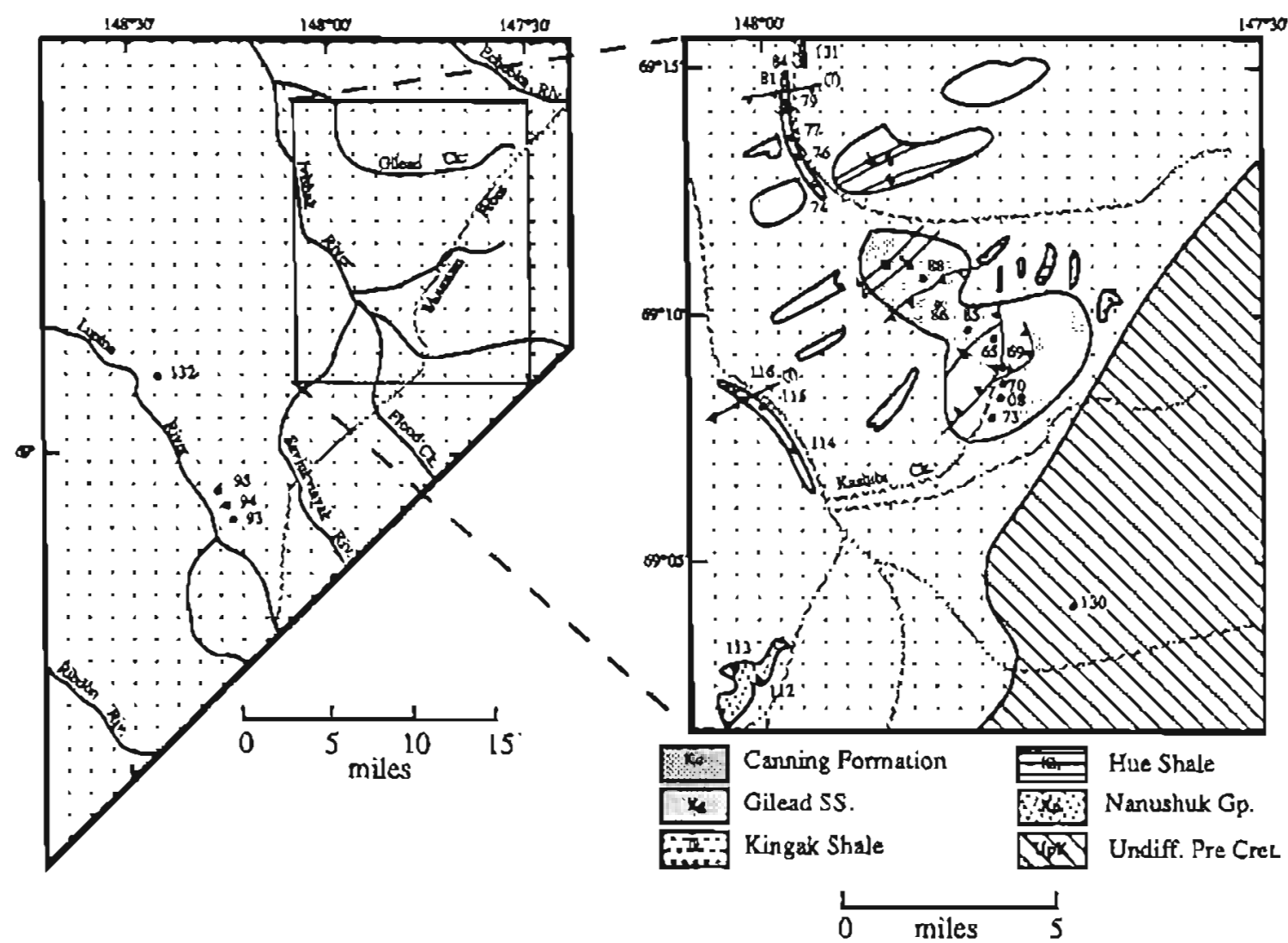

Figure 1. Regional map showing localities from which the 25 samples analyzed for this srudy were collected. Moving up-section, samples 93-95, 112-113, and 132 are from the Albian Nanushuk Group. Samples 65-79 are from the Albian Gilead Sandstone. Samples 79 and 116 are from further up-section in the Late Cretaceous Hue Shale. Samples 81,84 , and 131 are from the overlying Late Cretaceous Canning Formation. 


\section{INTRODUCTION}

This is a preliminary repor of apatite fission rack analyses of samples from the Gilead Creek region located in the foothills north of the Brooks Range between the Lupine and Echooka Rivers. Apatite grains were separated from 25 samples and analyzed in Melbourne Australia at the La Trobe University Fission Track Research Laboratory. Separations, grainmounts, and all analyses were completed by the author. Grain mounts used for both age and length data are archived at the Department of Geology of La Trobe University and can be accessed by written request to the author.

Each analysis includes two parts: 1) age report; and 2) track length distributions. The age report shows a listing of the individual grain ages, the resulting age and pertinent information used in determining the age. A guide to read the information is as follows:

\begin{tabular}{|c|c|}
\hline $\begin{array}{l}89 \text { POS 65A } \\
\text { IRRADIATION }\end{array}$ & $\begin{array}{l}\text {-Sample number and information } \\
\text {-In-house number for grouping samples from } \\
\text { the same irradiation package }\end{array}$ \\
\hline SLIDE NUMBER & - Number of individual mount from irradiation package \\
\hline & $\begin{array}{l}\text { - Number of each grain counted } \\
\text { - Number of spontaneous racks counted }\end{array}$ \\
\hline & - Number of induced tracks counted \\
\hline & - Number of area units counsed in grain \\
\hline Ratio & - Ratio of (NS/NI) for each grain \\
\hline $\mathrm{U}(\mathrm{ppm})$ & - Uranium concentration of each grain (ppm) \\
\hline RHOS & -Density of spontaneous tracks (per $\mathrm{cm}^{2}$ ) \\
\hline $\begin{array}{l}\text { RHOi } \\
\text { FT.AGE Ma) }\end{array}$ & $\begin{array}{l}\text {-Density of induced tracks (per } \mathrm{cm}^{2} \text { ) } \\
\text {-Individual fission track grain ages }\end{array}$ \\
\hline Chi Squared & $\begin{array}{l}\text {-Statistical test for determining multiple } \\
\text { grain populations }\end{array}$ \\
\hline$P($ chi squared) & -probability of less than $5 \%$ indicates multiple \\
\hline Variance of $S Q R$ & $\begin{array}{l}\text {-Statistical comparison of values of NS or NI } \\
\text { for all grains }\end{array}$ \\
\hline $\mathrm{N} / \mathrm{Ni}$ & $\begin{array}{l}\text {-Pooled ratio of }(\mathrm{Ns} / \mathrm{Ni}) \text {. Uses total number of } \\
\text { spontaneous and induced tracks counted for } \\
\text { whole sample. Value used in age calculation } \\
\text { if sample is of a single population }\end{array}$ \\
\hline $\begin{array}{l}\text { Mean Ratio } \\
\text { POOLED AGE }\end{array}$ & $\begin{array}{l}\text {-Average ratio of }(\mathrm{Ns} / \mathrm{Ni}) \text { for grains } \\
\text {-Age calculated using } \mathrm{Ns} / \mathrm{Ni} \text { (single population) }\end{array}$ \\
\hline MEAN AGE & $\begin{array}{l}\text {-Age calculated Using "Mean Ratio" (multiple } \\
\text { populations) }\end{array}$ \\
\hline
\end{tabular}

The track length distributions for each sample are histograms showing the relative numbers of tracks measured at a particular length. The mean length of the tracks measured, the standard deviation of the tracks measured, and the toral number of racks measured for each sample are reported in Table 1. 


\section{TECHNIOUES}

Apatites (and zircons) were separated from samples by conventional heavy liquid and magnetic rechniques. The apatire separates were mounted in epoxy resin on glass sides, ground and polished to expose internal surfaces of the grains, then etched to reveal the fossil fission racks. Neutron irradiations were carried out in a well thermalized flux in the Australian Atomic Energy Commissions HIFAR reactor. Thermal neuton fluences were monitored by counting tracks recorded in muscovite detectors attached to pieces of the NBS standard glass SRM612. Fission tracks in each mount were counted in transmitted light using a dry $80 x$ objective at a total magnification of $1250 x$. Wherever possible, tracks were counted over $\sim 20$ 25 grains in each mounr. For further descriprion, the methodology used for fission track counting has been described in detail by Moore et al. (1986) and Green (1986).

Analyses were carried out by the author in the laboratories of the La Trobe Universiry Fission Track Research Laboratory, Melbourne, Australia. Ages were calculated using the standard fission track age equation using the zeta calibration method (Hurford and Green, 1982) and errors were calculated using the techniques ourlined by Green (1981). In samples with a significant spread in single grain ages, the "conventional analysis", (as defined by Green 1981), based purely on Poissonian variation, is not valid. In such cases, which can be detected by a Chi squared statistic (Gaibraith, 1981), the mean age provides a useful measure (Green, 1981). The Chi squared stanistic indicates the probability that all grains counted beiong to a single population of ages. A probability of less than $5 \%$ is taken as evidence of a significant spread of single grain ages. A spread in individual grain ages can result either from inheritance of decrital grains from mixed source areas, or from differencial annealing in grains of different composition by heating within a narrow range of temperatures (Green et al. 1989).

Lengths of confined racks (Lal et al. 1969), in apacite only, were measured using the procedure outlined by Green (1986) and Green (1989). Only fully etched and horizontal "confined tracks" were measured (Laslett et al. 1982), in grains with polished surfaces parallel to prismatic crystal faces. Measurements were made under similar conditions to those employed for age determination. The lengths of suitable tracks were measured using a projection tube and a Hipad digitizing tablet calibrated using a stage micrometer (with $\mu \mathrm{m}$ 
divisions). As many tracks as possible (up to -100 ) were measured from each sample. The number of confined tracks measured for each sample are shown in Table 1 . In most cases less than 100 tracks were recorded due to a scarcity of aparite grains, low U concentration, and/or young ages for the samples. The number of tracks per each $\mu$ m division for each track length distribution is shown in Table 2.

\section{SAMPLE RESULTS}

For the purpose of this report, fission track ages were determined using $\sim 20-25$ individual grain ages (if possible) from each sample and as many confined track length measurements up to $\sim 100$. Typical yields for the samples were quite good and in most cases 25 dareable grains were found on each mount. Due to relatively young ages and in some cases, low uranium content (<10 ppm), only 3 mounts contained 100 or more confined tracks and an additional 6 mounts had between 50 and 100 tacks. Three mounts had less than 20 confined tracks. For all samples it was determined that the dated grains could represent a single population so the pooled age is presented for each.

When the data is plotted with respect to relative position within the suratigraphic section (Fig. 2) the apatite ages fall into a well-defined pattern. Apatite ages older than $\sim 45 \mathrm{Ma}$ from the upper part of the Hue Shale and the Canning Formation define a shallow slope in the age vrs. section plot. Ages younger than $\sim 40 \mathrm{Ma}$ from lower in the section in the Hue Shale, Nanushuk Group, Gilead Sandstone and pre-Cretaceous rocks do not change significantly down section and define a much steeper slope. Two breaks in the aparte age-stratigraphic section pattern are defined. The first separates data into two age groups (younger $<\sim 38 \mathrm{Ma}$, older $>\sim 44 \mathrm{Ma}$ ). The mean ages for the two groups are $35 \pm 2 \mathrm{Ma}$ for the younger, and $45 \pm 2 \mathrm{Ma}$ for the older. There is enough difference between the two groups to describe them as separate age components. The second break in the data is a small "break in slope" in the older group at $\sim 45$ Ma. 
Table 1. Sample results

\begin{tabular}{|c|c|c|c|c|c|}
\hline Sample No. & Unit & Lengths (\#) & Mean Len. $(\mu m \pm 1 \sigma)$ & S.D. & Age $(\mathrm{Ma} \pm 1 \sigma)$ \\
\hline \multicolumn{6}{|c|}{ Gilead Creek Traverse } \\
\hline $89 \operatorname{POS} 65 \mathrm{~A}$ & Gilead SS. & 58 & $13.37 \pm 0.23$ & 1.74 & $33.9 \pm 3.4$ \\
\hline 89 POS 69B & Gilead SS. & 47 & $13.86 \pm 0.22$ & 1.54 & $36.8 \pm 3.3$ \\
\hline 89 POS $70 B$ & Gilead SS. & 32 & $13.29 \pm 0.29$ & 1.64 & $33.2 \pm 3.4$ \\
\hline $89 \operatorname{POS} 73 A$ & Gilead SS. & 18 & $13.94 \pm 0.27$ & 1.14 & $29.8 \pm 3.8$ \\
\hline $89 \operatorname{POS} 74 \mathrm{~A}$ & Gilead SS. & 53 & $14.23 \pm 0.17$ & 1.20 & $33.2 \pm 3.2$ \\
\hline 89 POS $76 \mathrm{C}$ & Gilead SS. & 35 & $14.02 \pm 0.19$ & 1.10 & $37.9 \pm 3.5$ \\
\hline $89 \operatorname{POS} 778$ & Gilead SS. & 23 & $13.83 \pm 0.26$ & 1.22 & $37.9 \pm 3.5$ \\
\hline 89 POS 79B & Hue Sh. & 56 & $14.33 \pm 0.13$ & 1.01 & $34.5 \pm 3.1$ \\
\hline 89 POS $81 \mathrm{~A}$ & Canning Fm. & 103 & $14.51 \pm 0.13$ & 1.36 & $44.4 \pm 2.5$ \\
\hline $89 \operatorname{POS} 84 \mathrm{~A}$ & Canning Fm. & 63 & $14.42 \pm 0.12$ & 0.98 & $43.1 \pm 5.1$ \\
\hline 89 POS 85A & Gilead SS. & 33 & $13.82 \pm 0.18$ & 1.05 & $36.5 \pm 3.4$ \\
\hline 89 POS $86 \mathrm{~A}$ & Gilead SS. & 56 & $14.01 \pm 0.08$ & 0.59 & $39.1 \pm 3.8$ \\
\hline 89 POS 88A & Gilead SS. & 36 & $14.05 \pm 0.17$ & 1.00 & $37.3 \pm 4.3$ \\
\hline 89 POS 130A & Lisburne LS. & $\cdot$ & - & - & $32.9 \pm 6.4$ \\
\hline 89 POS $131 \mathrm{~A}$ & Canning Fm. & 26 & $12.55 \pm 0.42$ & 2.12 & $50.5 \pm 4.7$ \\
\hline 89 MR 08A & Gilead SS. & 11 & $13.84 \pm 0.36$ & 1.18 & $34.5 \pm 4.8$ \\
\hline \multicolumn{6}{|c|}{ Lupine River Traverse } \\
\hline 89 POS 93A & Nanushuk Gp. & 104 & $14.52 \pm 0.13$ & 1.31 & $35.0 \pm 2.6$ \\
\hline 89 POS 94A & Nanushuk Gp. & 57 & $14.42 \pm 0.13$ & 0.98 & $34.0 \pm 7.6$ \\
\hline 89 POS 95A & Nanushuk Gp. & 40 & $13.83 \pm 0.35$ & 2.18 & $36.0 \pm 2.9$ \\
\hline $89 \operatorname{POS} 132 \mathrm{~A}$ & Nanushuk Gp. & 32 & $13.78 \pm 0.19$ & 1.05 & $36.6 \pm 3.8$ \\
\hline \multicolumn{6}{|c|}{ Ivishak River Traverse } \\
\hline 89 POS 112A & Nanushuk Gp. & 41 & $14.01 \pm 0.10$ & 0.65 & $38.2 \pm 4.7$ \\
\hline 89 POS 113A & Nanushuk Gp. & 17 & $13.87 \pm 0.23$ & 0.95 & $36.9 \pm 3.8$ \\
\hline 89 POS 114A & Gilead SS. & 32 & $13.67 \pm 0.23$ & 1.30 & $38.6 \pm 3.8$ \\
\hline 89 POS 115A & Gilead SS. & 48 & $13.97 \pm 0.16$ & 1.08 & $37.5 \pm 5.9$ \\
\hline 89 POS $116 \mathrm{~A}$ & Hue Sh. & 104 & $15.09 \pm 0.08$ & 0.78 & $46.2 \pm 2.9$ \\
\hline
\end{tabular}


Table 2. Track length data

Sample Track Length Range $(\mu \mathrm{m})$

Number $<5 \quad 5-6 \quad 6-7 \quad 7-8 \quad 8-9$ 9-10 $10-11 \quad 11-12 \quad 12-13 \quad 13-14 \quad 14-15 \quad 15-16 \quad 16-17>17$

Gilead Creek Region

$65 \mathrm{~A}$

$\begin{array}{lll}0 & 0 & 1\end{array}$

$69 \mathrm{~B}$

$\begin{array}{llllll}0 & 0 & 0 & 0 & 1 & 0\end{array}$

$70 \mathrm{~B}$

$\begin{array}{llll}0 & 0 & 0 & 0\end{array}$

$73 \mathrm{~A}$

00

$74 \mathrm{~A}$

$76 \mathrm{C}$

$\begin{array}{lll}0 & 0 & 0\end{array}$

$77 \mathrm{~B}$

00

$79 \mathrm{~B}$

$\begin{array}{lll}0 & 0\end{array}$

$81 \mathrm{~A}$

$\begin{array}{lll}0 & 0\end{array}$

$84 \mathrm{~A}$

$\begin{array}{lll}0 & 0 & 0\end{array}$

0

$85 \mathrm{~A}$

$\begin{array}{lll}0 & 0\end{array}$

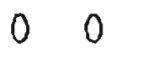

1

$86 \mathrm{~A}$

$88 \mathrm{~A}$

$130 \mathrm{~A}$

$131 \mathrm{~A}$

$\begin{array}{llllll}0 & 0 & 0 & 0 & 0 & 0\end{array}$

MROBA

$\begin{array}{llllll}0 & 0 & 0 & 0 & 0 & 0\end{array}$

\section{Lupine River Traverse}

93A 000

$94 \mathrm{~A} \quad 0 \quad 0000000$

95A $\quad 1 \quad 0 \quad 0010001$

$132 \mathrm{~A}$

Ivishak River Traverse

$\begin{array}{llllllllllccccc}112 \mathrm{~A} & 0 & 0 & 0 & 0 & 0 & 0 & 0 & 0 & 3 & 13 & 24 & 1 & 0 & 0 \\ 113 \mathrm{~A} & 0 & 0 & 0 & 0 & 0 & 0 & 0 & 1 & 2 & 7 & 5 & 2 & 0 & 0 \\ 114 \mathrm{~A} & 0 & 0 & 0 & 0 & 0 & 1 & 2 & 1 & 1 & 11 & 13 & 3 & 0 & 0 \\ 115 \mathrm{~A} & 0 & 0 & 0 & 0 & 0 & 0 & 1 & 2 & 3 & 14 & 24 & 3 & 1 & 0 \\ 116 \mathrm{~A} & 0 & 0 & 0 & 0 & 0 & 0 & 0 & 0 & 1 & 6 & 39 & 47 & 10 & 1\end{array}$




\section{PRELIMINARY INTERPRETATIONS}

All aparite ages ( 29-50 Ma) for individual samples are much less than their statigraphic ages (>80 Ma) indicating substantial age reduccion following deposition. The fission track data delineate a minimum of two components of cooling due to uplift for the Gilead Creek region at $\sim 35 \mathrm{Ma}$ and $\sim 45 \mathrm{Ma}$. The data also indicates that it is possible that the region experienced an earlier phase of cooling due to uplift in the Paleocene.

The lower part of the stratigraphic section, in the Albian Nanushuk Group and Gilead Sandstone, record a phase of cooling due to uplift at $\sim 35 \mathrm{Ma}$ A cotal of 19 ages range between $\sim 29$ to $\sim 38 \mathrm{Ma}$ and have mean track lengths between $\sim 13.2$ and $\sim 14.5$ with narrow distributions (s.d. $\sim 1.00$ ). This is indicative of rapid cooling from temperatures $>110^{\circ} \mathrm{C}$ at the time given by the ages (mean $\sim 35 \pm 2 \mathrm{Ma}$ ). The presence of high paleotemperatures $>110^{\circ} \mathrm{C}$ is supported by vitrinite values of $\sim 1.5 \%$ from the Gilead Sandstone south of Gilead Creek (Reifenstuhl, 1990). The lower part of the section is separated from the upper secrion by a proposed thrust in the Hue Shale.

Cooling due to uplift at $\sim 45 \mathrm{Ma}$ is seen by the The "break in slope" at $45 \mathrm{Ma}$ in the older group (Fig. 2). This break marks the base of an uplifted annealing zone and represents the time of initiation of cooling due to uplift. The shallow gradient defined above the break in slope is an inherited characteristic from the pre-uplift aparte annealing zone. Ages of $\sim 45 \mathrm{Ma}$ defining the steeper part of the apatite age profile are "uplift" ages, that is, they were recorded after uplift began. Prior to this, they lay below the base of the annealing zone at temperatures too high to record tracks.

The track length data give further evidence that the "break in slope" in the older group is indeed present. Above the break the confined track lengths have been shorened to $\sim 12 \mu \mathrm{m}$ indicating exposure to temperatures in the range of $80-100^{\circ} \mathrm{C}$ following deposition. Below the break the lengths are all long $(>14 \mu \mathrm{m})$ which indicate that the rocks have not experienced temperanures $>\sim 50^{\circ} \mathrm{C}$. Since the fission track ages are substantially less than stratigraphic ages this relationship is only possible where samples below the break have been totally annealed and then rapidly cooled at the time given by the fission track age. 


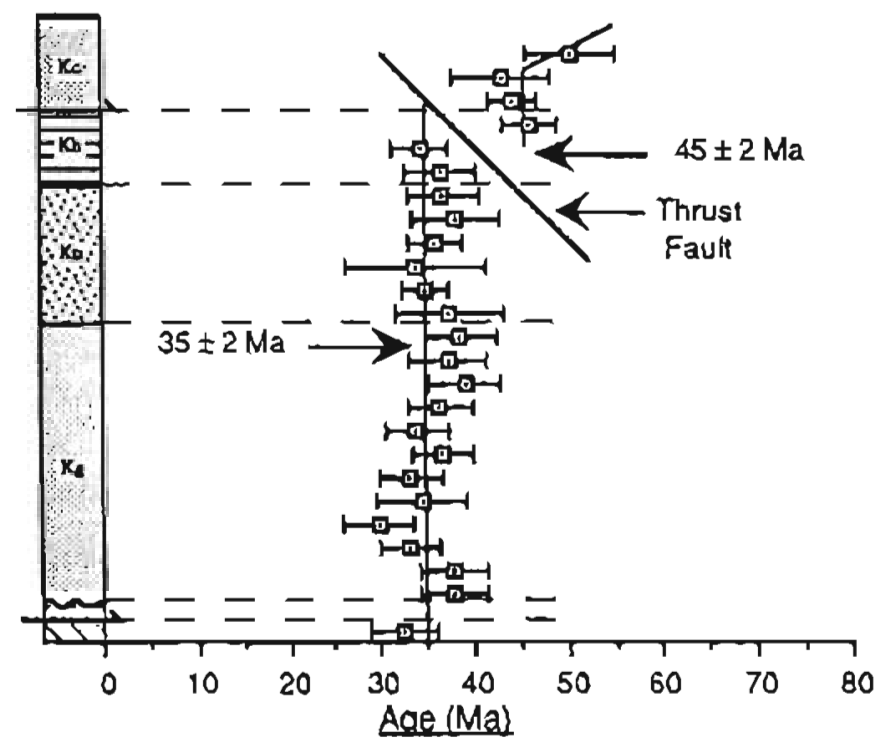

Figure 2. Apatite fission track results for samples from the Gilead Creek region plotted against their relarive position in the stratigraphic secrion shown along the left side. Error bars are one standard deviation. These define the "regional" partem consisting of a three-stage uplift history. Please see text for derails.

Though inconclusive, the data from the upper-most sample (89 POS 131A) could possibly indicate an older phase of cooling due to uplift in the Paleocene. The fission rack data, as previously described, indicate that following cooling the sample has seen maximum temperatures in the range $-80-100^{\circ} \mathrm{C}$ since deposition. Vitrinite data though indicates the sample has seen much higher iemperatures above $150^{\circ} \mathrm{C}$ (Dave Howell, personal communication). Therefore, following deposition, that part of the section has experienced temperatures much greater than required to totally anneal any existing fission tacks. Thus the corrected fission rack age for the sample (corrected for track length reduction) of $\sim 59 \pm 3 \mathrm{Ma}$ could indicate an earlier phase of cooling from $>110^{\circ} \mathrm{C}$ in the Paleocene which occured prior to reburial to $\sim 80-100^{\circ} \mathrm{C}$ during the Oligocene and subsequent cooling at $\sim 45 \mathrm{Ma}$. The presence of this Paleocene event in the foothills of the Brooks Range is well documented from other fission track data from the north flank of the Brooks Range (O'Sullivan, 1988; O'Sullivan, 1989; O'Sullivan, 1990; O'Sullivan et. al., 1989, 1990a,b).

Based primarily on the fission rack data, it is believed that after deposicion of the section by the Late Cretaceous, heating associated with burial resulted in apatite fission track ages being totally annealed. Subsequently, three phases of rapid uplift occurred during the Tertiary due to thrusting in the Brooks Range. The initial phase (proposed) occurred during the Paleocene. 
This was followed by burial resulting in reheating of most of the secrion to elevated temperatures $\left(>110^{\circ} \mathrm{C}\right)$ while the upper part of the section experienced temperarures in the range $\sim 80-100^{\circ} \mathrm{C}$. Subsequently a second phase of uplift occurred during the Eocene $(\sim 45 \mathrm{Ma})$ as recorded by the samples from the upper Hue Shale and the Canning Formation. Finally, a third phase of uplift occurred during the Oligocene ( $-35 \mathrm{Ma})$ as recorded by the lower part of the section. This third phase is a result of thrusting along a proposed fault in the Hue Shale. 


\section{REFERENCES}

Galbraith, R.F. (1981). On statistical models for fission track counts. Mathemacical Geology, v. 13: $471-488$.

Green. P.F. (1981). A new look at staristics in fission track dating. Nuclear Tracks 5: 77-86.

Green, P.F. (1986). On the thermo-tectonic evolution of Northem England: evidence from fission track analysis. Geology, v. 5: 493-506.

Green, P.F. (1989). Thermal and tectonic history of the East Midlands shelf (onshore UK) and surrounding regions assessed by apatite fission track analysis. Journal of the London Geological Society, v. 146: 755-773.

Green, P.F., Duddy, I.R., Laslett, G.M., Hegarty, K.A., Gleadow, A.J.W., and Lovering, J.F. (1989). Thermal annealing of fission tracks in apatite 4. Qualitative modelling techniques and extensions to geological timescales. Chemical Geology (Isorope Geoscience Section), v. 79: 155-182.

Hurford, A.J. and Green, P.F. (1982). A users' guide to fission-track dating calibration. Earth and Planetary Science Letters, v. 59: 343-354.

Hurford, A.J. and Green, P.F. (1983). The zeta age calibration of fission rack dating. Isotope Geoscience 1: 285-317

Lal, D., Rajan, R.S. and Tamhane, A.S. (1969). Chemical composition of nuclei of $Z>22$ in cosmic rays using meteoric minerals as detectors. Nature, v. 221: 33-37.

Lasletr, G.M., Kendall, W.S., Gleadow, A.J.W. and Duddy, I.R. (1982). Bias in measurement of fission track length distributions. Nuclear Tracks 6: 79-85.

Moore, M.E., Gleadow, A.J.W. and Lovering, J.F. (1986). Thermal evolution of rifted continental margins: new evidence from fission tracks in basement apatites from southeastem Australia. Earh and Planetary Science Letters, v. 78: 255-270.

O'Sullivan, P.B. (1988). Apatite fission track study of the thermal history of Permian to Tertiary sedimentary rocks in the Arctic National Wildlife Refuge, northeastern Alaska. Alaskz Division of Geological and Geophysical Surveys Public Data File 88-42: $142 \mathrm{p}$.

O'Sullivan, P.B. (1989). Preliminary Results of 14 Apatite Fission Track Analyses of Samples From The Umiat and Colville River Region, North Slope Alaska. Alaska Division of Geological and Geophysical Surveys Public Data File 89-2E: 21 p.

O'Sullivan, P.B. (1990). Preliminary results of 11 apatite fission analyses from the Galbraith Lake- Toolik Lake region, North Slope, Alaska: Alaska Geological and Geophysical Surveys Public Data File 90-7a, 17 p.

O'Sullivan, P.B., Decker, J.E., and Bergman, S.C. (1989). Apatite fission-track study of the thermal history of Permian to Tertiary sedimentary rocks in the Arcic National Wildlife Refuge, northeastem Alaska. Geological Society of America Abstracts with Programs, v. 21 , no. 5, p. 126.

O'Sullivan, P.B., Decker, J., Bergman, S.C. and Wallace, W.K. (19902). Constraints by aparite fission track analysis on the cooling times due to uplift of the northeastem Brooks Range, Alaska (abs.): American Association of Petroleum Geologists Bulletin. v. 74. p. 733. 
O'Sullivan, P.B.. Decker, J., Bergman. S.C. and Wallace. W.K. (1990b). Apacite fission track evidence for Tertiary uplift in the northeastern Brooks Range, Alaska (abs.): in Abstracts Volume, Seventh International Conference on Geochronolgy, Cosmochronology and Isotope Geology.

Reifenstuhl, R.R. (1990). Vitrinite reflectance data, for some early Tertiary through Jurassic outcrop samples, Northeastem Alaska. Alaska Division of Geological and Geophysical Surveys Public Data File 90-5A: 3 p. 


\section{GRAIN-AGE DATA FROM GILEAD CREEK REGION}

89 POS 65A Gilead SS - Gilend Ck.

IRRADIATION LU079

SLIDE NUMBER 8

COUNTED BY: P. O'Sullivar

\begin{tabular}{|c|c|c|c|c|c|c|c|c|}
\hline No. & $\mathrm{Ns}$ & $\mathrm{Ni}$ & $\mathrm{Na}$ & RATIO & $U(\mathrm{ppm})$ & RHOS & RHOi & F.T. AGE (Ma) \\
\hline 1 & 5 & 34 & 28 & 0.147 & 8.6 & $1.984 \mathrm{E}+05$ & $1.349 E+06$ & $52.8 \pm 25.3$ \\
\hline 2 & 7 & 33 & 9 & 0.212 & 26.1 & $8.642 E+05$ & $4.074 E+06$ & $76.1 \pm 31.7$ \\
\hline 3 & 8 & 76 & 16 & 0.105 & 33.8 & $5.556 \mathrm{E}+05$ & $5.278 E+06$ & $37.9 \pm 14.1$ \\
\hline 4 & 0 & 6 & 25 & 0.000 & 1.7 & $0.000 \mathrm{E}+00$ & $2.667 E+05$ & $0.0 \pm \quad 0.0$ \\
\hline 5 & 3 & 26 & 20 & 0.115 & 9.2 & $1.667 \mathrm{E}+05$ & $1.444 E+06$ & $41.5 \pm 25.3$ \\
\hline 6 & 0 & 4 & 25 & 0.000 & 1.1 & $0.000 \mathrm{E}+00$ & $1.778 E+05$ & $0.0 \pm \quad 0.0$ \\
\hline 7 & 0 & 8 & 25 & 0.000 & 2.3 & $0.000 E+00$ & $3.556 E+05$ & $0.0 \pm 0.0$ \\
\hline 8 & 1 & 13 & 18 & 0.077 & 5.1 & $6.173 E+04$ & $8.025 E+05$ & $27.7 \pm 28.7$ \\
\hline 9 & 0 & 7 & 16 & 0.000 & 3.1 & $0.000 E+00$ & $4.861 E+05$ & $0.0 \pm 0.0$ \\
\hline 10 & 5 & 51 & 15 & 0.098 & 24.2 & $3.7048+05$ & $3.778 E+06$ & $35.3 \pm 16.5$ \\
\hline 11 & 0 & 4 & 16 & 0.000 & 1.8 & $0.000 \mathrm{E}+00$ & $2.778 E+05$ & $0.0 \pm 0.0$ \\
\hline 12 & 0 & 8 & 14 & 0.000 & 4.1 & $0.000 \mathrm{E}+00$ & $6.349 E+05$ & $0.0 \pm$ \\
\hline 13 & 2 & 60 & 40 & 0.033 & 10.7 & $5.556 \mathrm{E}+04$ & $1.667 E+06$ & $12.0 \pm$ \\
\hline 14 & 0 & 6 & 25 & 0.000 & 1.7 & $0.000 E+00$ & $2.667 \mathrm{E}+05$ & $0.0 \pm$ \\
\hline 15 & 0 & 9 & 20 & 0.000 & 3.2 & $0.000 E+00$ & $5.000 E+05$ & $0.0 \pm$ \\
\hline 16 & 1 & 5 & 32 & 0.200 & 1.1 & $3.472 E+04$ & $1.736 E+05$ & $71.8 \pm 78.6$ \\
\hline 17 & 2 & 15 & 32 & 0.133 & 3.3 & $6.944 E+04$ & $5.208 E+05$ & $47.9 \pm 36.1$ \\
\hline 18 & 16 & 209 & 24 & 0.077 & 62.0 & 7.40TE +0.5 & $9.676 \mathrm{E}+06$ & $27.6 \pm 7.2$ \\
\hline 19 & 21 & 223 & 25 & 0.094 & 63.5 & $9.333 \mathrm{E}+05$ & $9.911 \mathrm{E}+06$ & $33.9 \pm 7.8$ \\
\hline 20 & 0 & 18 & 36 & 0.000 & 3.6 & $0.000 E+\infty 0$ & $5.556 E+05$ & $0.0 \pm 0.0$ \\
\hline 21 & 1 & 6 & 28 & 0.167 & 1.5 & $3.968 E+04$ & $2.381 E+05$ & $59.9 \pm 64.7$ \\
\hline 22 & 3 & 32 & 12 & 0.094 & 19.0 & $2.778 E+05$ & $2.963 \mathrm{E}+06$ & $33.7 \pm 20.4$ \\
\hline 23 & 0 & 7 & 25 & 0.000 & 2.0 & $0.000 \mathrm{E}+\infty 0$ & $3.111 E+05$ & $0.0 \pm \quad 0.0$ \\
\hline 24 & 29 & 249 & 20 & 0.116 & 88.6 & $1.611 E+06$ & $1.383 E+07$ & $41.9 \pm 8.3$ \\
\hline \multirow[t]{2}{*}{25} & 6 & 58 & 18 & 0.103 & 22.9 & $3.704 E+05$ & $3.580 \mathrm{E}+06$ & $37.2 \pm 16.0$ \\
\hline & 110 & 1167 & & & 14.7 & $2.167 E+05$ & $2.299 E+06$ & \\
\hline
\end{tabular}

Area of basic unit $=.0000009 \mathrm{~cm}-2$

Chi Squared $=17.532$ with 24 degrees of freedom

$\mathrm{P}($ chi squared $)=82.5 \%$

Correlation Coefficient $=0.968$

Variance of $S Q R(N s)=2.46$

Variance of SQR(Ni) $=16.90$

Age Dispersion $=0.878 \%($ did not converge $)$

$\mathrm{Ns} / \mathrm{Ni}=0.094 \pm 0.009$

Mean Ratio $=0.071 \pm 0.014$

Ages calculated using a zeta of $352.7 \pm 5$ for SRM612 glass

Rho $D=2.046 \mathrm{E}+06 \mathrm{~cm}-2: \quad \mathrm{ND}=4604$

POOLED AGE $=33.9 \pm 3.5 \mathrm{Ma}$

MEAN AGE $=25.5 \pm 5.0 \mathrm{Ma}$ 
89 POS 69B Gilead SS - Gilead CK.

IRRADIATION LU079

SLIDE NUMBER 9

COUNTED BY: P. O'Sullivan

\begin{tabular}{|c|c|c|c|c|c|c|c|c|}
\hline No. & Ns & $\mathrm{Ni}$ & $\mathrm{Na}$ & RATIO & $U$ (ppm) & RHOs & RHOi & F.T. AGE (Ma) \\
\hline 1 & 1 & 8 & 20 & 0.125 & 2.8 & $5.556 E+04$ & $4.444 E+05$ & $44.9 \pm 47.7$ \\
\hline 2 & 1 & 3 & 25 & 0.333 & 0.9 & $4.444 E+04$ & $1.333 E+05$ & $119.2 \pm 137.6$ \\
\hline 3 & 24 & 212 & 28 & 0.113 & 53.9 & $9.524 E+05$ & $8.413 E+06$ & $40.7 \pm 8.8$ \\
\hline 4 & 0 & 1 & 16 & 0.000 & 0.4 & $0.000 \mathrm{E}+00$ & $6.944 \mathrm{E}+04$ & $0.0 \pm$ \\
\hline 5 & 2 & 16 & 28 & 0.125 & 4.1 & $7.936 \mathrm{E}+04$ & $6.349 \mathrm{E}+05$ & $44.9 \pm 33.7$ \\
\hline 6 & 5 & 94 & 16 & 0.053 & 41.8 & $3.472 E+05$ & $6.528 \mathrm{E}+06$ & $19.2 \pm 8.8$ \\
\hline 7 & 1 & 1 & 21 & 1.000 & 0.3 & $5.291 E+04$ & $5.291 E+04$ & $351.1 \pm 496.5$ \\
\hline 8 & 21 & 180 & 30 & 0.117 & 42.7 & $7.778 E+05$ & $6.667 E+06$ & $42.0 \pm 9.7$ \\
\hline 9 & 0 & 3 & 20 & 0.000 & 1.1 & $0.000 E+00$ & $1.667 \mathrm{E}+05$ & $0.0 \pm \quad 0.0$ \\
\hline 10 & 8 & 77 & 25 & 0.104 & 21.9 & $3.556 \mathrm{E}+05$ & $3.422 E+06$ & $37.4 \pm 13.9$ \\
\hline 11 & 3 & 17 & 20 & 0.176 & 6.0 & $1.667 \varepsilon+05$ & $9.444 E+05$ & $63.4 \pm 39.7$ \\
\hline 12 & 0 & 4 & 30 & 0.000 & 0.9 & $0.000 \mathrm{E}+00$ & $1.481 \mathrm{E}+05$ & $0.0 \pm 0.0$ \\
\hline 13 & 0 & 3 & 25 & 0.000 & 0.9 & $0.000 E+00$ & $1.333 E+05$ & $0.0 \pm$ \\
\hline 14 & 3 & 26 & 28 & 0.115 & 6.6 & $1.190 E+05$ & $1.032 E+06$ & $41.5 \pm 25.3$ \\
\hline 15 & 3 & 14 & 18 & 0.214 & 5.5 & $1.852 E+05$ & $8.642 E+05$ & $76.9 \pm 48.9$ \\
\hline 16 & 0 & 1 & 24 & 0.000 & 0.3 & $0.000 \mathrm{E}+00$ & $4.630 E+04$ & $0.0 \pm 0.0$ \\
\hline 17 & 0 & 8 & 21 & 0.000 & 2.7 & $0.000 E+00$ & $4.233 E+05$ & $0.0 \pm$ \\
\hline 18 & 5 & 51 & 42 & 0.098 & 8.6 & $1.323 E+05$ & $1.349 E+06$ & $35.3 \pm 16.5$ \\
\hline 19 & 0 & 2 & 14 & 0.000 & 1.0 & $0.000 \mathrm{E}+\infty$ & $1.587 \mathrm{E}+05$ & $0.0 \pm 0.0$ \\
\hline 20 & 11 & 121 & 30 & 0.091 & 28.7 & $4.074 E+05$ & $4.481 \mathrm{E}+06$ & $32.7 \pm 10.3$ \\
\hline 21 & 0 & 6 & 32 & 0.000 & 1.3 & $0.000 E+\infty 0$ & $2.083 E+05$ & $0.0 \pm \quad 0.0$ \\
\hline 22 & 0 & 2 & 21 & 0.000 & 0.7 & $0.000 \mathrm{E}+00$ & $1.058 E+05$ & $0.0 \pm$ \\
\hline 23 & 21 & 191 & 35 & 0.110 & 38.8 & $6.667 \mathrm{E}+05$ & $6.063 E+06$ & $39.5 \pm$ \\
\hline 24 & 2 & 11 & 36 & 0.182 & 2.2 & $6.173 \mathrm{E}+04$ & $3.395 E+05$ & $65.3 \pm 50.2$ \\
\hline \multirow[t]{2}{*}{25} & 34 & 366 & 60 & 0.093 & 43.4 & $6.296 \mathrm{E}+05$ & $6.778 E+06$ & $33.4 \pm 6.0$ \\
\hline & 145 & 1418 & & & 15.2 & $2.423 E+05$ & $2.369 \mathrm{E}+06$ & \\
\hline
\end{tabular}

Area of basic unit $=.0000009 \mathrm{~cm}-2$

Chi Squarcd $=14.288$ wich 24 degrees of freedom

$P($ chi squared $)=94.0 \%$

Correlation Coefficient $=0.986$

Variance of SQR(Ns) $=3.17$

Variance of $S Q R(N i)=26.90$

Age Dispersion $=0.002 \%$ (did not converge)

$\mathrm{Ns} / \mathrm{Ni}=0.102 \pm 0.009$

Mean Ratio $=0.122 \pm 0.040$

Ages calculated using a zecz of $352.7 \pm 5$ for SRM612 glass

Rho $D=2.046 \mathrm{E}+06 \mathrm{~cm}-2 ; \quad \mathrm{ND}=4604$

POOLED AGE $=36.8 \pm 3.3 \mathrm{Ma}$

MEAN AGE $=43.9 \pm 14.5 \mathrm{Ma}$ 
89 POS 7OB Gilead SS - Gilead Ck.

IRRADLATION LU079

SLIDE NUMBER 10

COUNTED BY: P. O'Sullivan

\begin{tabular}{|c|c|c|c|c|c|c|c|c|}
\hline No. & Ns & $\mathrm{Ni}$ & $\mathrm{Na}$ & RATIO & $U$ (ppm) & RHOS & RHOi & F.T. AGE (Ma) \\
\hline 1 & 0 & 3 & 25 & 0.000 & 0.90 & $0.000 E+\infty 0$ & $1.333 \mathrm{E}+05$ & $0.0 \pm 0.0$ \\
\hline 2 & 0 & 8 & 36 & 0.000 & 1.6 & $0.000 E+00$ & $2.469 E+05$ & $0.0 \pm$ \\
\hline 3 & 0 & 1 & 25 & 0.000 & 0.3 & $0.000 E+00$ & $4,444 E+04$ & $0.0 \pm$ \\
\hline 4 & 1 & 21 & 16 & 0.048 & 9.3 & $6.944 E+04$ & $1.458 E+06$ & $17.2 \pm 17.6$ \\
\hline 5 & 5 & 28 & 20 & 0.179 & 10.0 & $2.778 E+05$ & $1.556 \mathrm{E}+06$ & $64.1 \pm 31.2$ \\
\hline 6 & 29 & 319 & 45 & 0.091 & 50.4 & $7.160 \mathrm{E}+05$ & $7.877 \mathrm{E}+06$ & $32.7 \pm$ \\
\hline 7 & 8 & 76 & 40 & 0.105 & 13.5 & $2.222 \mathrm{E}+05$ & $2.11 \mathrm{IE}+06$ & $37.9 \pm 14.1$ \\
\hline 8 & 0 & 4 & 18 & 0.000 & 1.6 & $0.000 \mathrm{E}+00$ & $2.469 E+05$ & $0.0 \pm 0.0$ \\
\hline 9 & 0 & 7 & 16 & 0.000 & 3.1 & $0.000 E+00$ & $4.861 E+05$ & $0.0 \pm$ \\
\hline 10 & 0 & 8 & 18 & 0.000 & 3.2 & $0.000 \mathrm{E}+\infty$ & $4.938 \mathrm{E}+05$ & $0.0 \pm$ \\
\hline 11 & 0 & 9 & 14 & 0.000 & 4.6 & $0.000 \mathrm{E}+00$ & $7.143 \mathrm{E}+05$ & $0.0 \pm$ \\
\hline 12 & 16 & 207 & 40 & 0.077 & 36.8 & $4.444 E+05$ & $5.750 E+06$ & $27.8 \pm$ \\
\hline 13 & 1 & 6 & 28 & 0.167 & 1.5 & $3.968 E+04$ & $2.381 E+05$ & $59.9 \pm 64.7$ \\
\hline 14 & 29 & 259 & 42 & 0.112 & 43.9 & $7.672 \varepsilon+05$ & $6.852 \mathrm{E}+06$ & $40.3 \pm 7.9$ \\
\hline 15 & 1 & 3 & 25 & 0.333 & 0.9 & $4.444 E+04$ & $1.333 E+05$ & $119.2 \pm 137.6$ \\
\hline 16 & 2 & 16 & 28 & 0.125 & 4.1 & $7.936 \mathrm{E}+04$ & $6.349 E+05$ & $44.9 \pm 33.7$ \\
\hline 17 & 5 & 89 & 18 & 0.056 & 35.2 & $3.086 \mathrm{E}+05$ & $5.494 E+06$ & $20.2 \pm 9.3$ \\
\hline 18 & 0 & 3 & 20 & 0.000 & 1.1 & $0.000 \mathrm{E}+00$ & $1.667 E+05$ & $0.0 \pm$ \\
\hline 19 & 0 & 4 & 30 & 0.000 & 0.9 & $0.000 E+\infty$ & $1.481 E+05$ & $0.0 \pm$ \\
\hline 20 & 3 & 15 & 18 & 0.200 & 5.9 & $1.852 E+05$ & $9.259 \mathrm{E}+05$ & $71.8 \pm 45.4$ \\
\hline 21 & 5 & 52 & 28 & 0.096 & 13.2 & $1.984 \mathrm{E}+05$ & $2.063 \mathrm{E}+06$ & $34.6 \pm 16.2$ \\
\hline 22 & 0 & 6 & 30 & 0.000 & 1.4 & $0.000 \mathrm{E}+00$ & $2.222 E+05$ & $0.0 \pm 0.0$ \\
\hline 23 & 2 & 11 & 36 & 0.182 & 2.2 & $6.173 E+04$ & $3.395 \mathrm{E}+05$ & $65.3 \pm 50.2$ \\
\hline 24 & 1 & 7 & 20 & 0.143 & 2.5 & $5.556 \mathrm{E}+04$ & $3.889 E+05$ & $51.3 \pm 54.9$ \\
\hline 25 & 0 & 8 & 25 & 0.000 & 2.3 & $0.000 \mathrm{E}+\infty$ & $3.556 \mathrm{E}+05$ & $0.0 \pm 0.0$ \\
\hline & 108 & 1170 & & & 12.6 & $1.815 E+05$ & $1.967 E+06$ & \\
\hline
\end{tabular}

Area of basic unit $=.0000009 \mathrm{~cm}-2$

Chi Squared $=15.191$ with 24 degrees of freedom

$\mathrm{P}($ chi squared $)=91.5 \%$

Correlacion Coefficient $=0.981$

Variance of $S Q R(N)=2.70$

Variance of $S Q R(N i)=22.02$

Age Dispersion $=0.078 \%$ (did not converge)

$\mathrm{Ns} / \mathrm{Ni}=0.092 \pm 0.009$

Mean Ratio $=0.077 \pm 0.018$

Ages calculated using a zeta of $352.7 \pm 5$ for SRM612 glass

Rho $\mathrm{D}=2.046 \mathrm{E}+06 \mathrm{~cm}-2 ; \quad \mathrm{ND}=4604$

POOLED AGE $=33.2 \pm 3.4 \mathrm{Ma}$

MEAN AGE $=27.6 \pm 6.4 \mathrm{Ma}$ 
89 POS 73A Gilead SS - Gilead CK.

IRRADLATION LU179

SLIDE NUMBER 11

COUNIED BY: P. O'Sullivan

\begin{tabular}{cccccccccc}
\hline No. & Ns & Ni & Na & RATIO & \multicolumn{2}{c}{ U (ppm) } & RHOs & RHOi & F.T. AGE (Ma) \\
\hline 1 & 1 & 21 & 24 & 0.048 & 6.2 & $4.630 \mathrm{E}+04$ & $9.722 \mathrm{E}+05$ & $17.2 \pm 17.6$ \\
2 & 2 & 17 & 20 & 0.118 & 6.0 & $1.131 \mathrm{E}+05$ & $9.444 \mathrm{E}+05$ & $42.3 \pm 31.6$ \\
3 & 1 & 1 & 25 & 1.000 & 0.3 & $4.444 \mathrm{E}+04$ & $4.444 \mathrm{E}+04$ & $351.1 \pm 496.5$ \\
4 & 1 & 9 & 25 & 0.111 & 2.6 & $4.444 \mathrm{E}+04$ & $4.000 \mathrm{E}+05$ & $40.0 \pm 42.1$ \\
5 & 0 & 14 & 25 & 0.000 & 4.0 & $0.000 \mathrm{E}+00$ & $6.222 \mathrm{E}+05$ & $0.0 \pm 0.0$ \\
6 & 5 & 61 & 24 & 0.082 & 18.1 & $2.315 \mathrm{E}+05$ & $2.824 \mathrm{E}+06$ & $29.5 \pm 13.7$ \\
7 & 2 & 11 & 25 & 0.182 & 3.1 & $8.889 \mathrm{E}+04$ & $4.889 \mathrm{E}+05$ & $65.3 \pm 50.2$ \\
8 & 2 & 8 & 20 & 0.250 & 2.8 & $1.111 \mathrm{E}+05$ & $4.444 \mathrm{E}+05$ & $89.6 \pm 70.8$ \\
9 & 1 & 8 & 15 & 0.125 & 3.8 & $7.407 \mathrm{E}+04$ & $5.926 \mathrm{E}+05$ & $44.9 \pm 47.7$ \\
10 & 3 & 60 & 25 & 0.050 & 17.1 & $1.333 \mathrm{E}+05$ & $2.667 \mathrm{E}+06$ & $18.0 \pm 10.7$ \\
11 & 9 & 120 & 25 & 0.075 & 34.1 & $4.000 \mathrm{E}+05$ & $5.333 \mathrm{E}+06$ & $27.0 \pm 9.3$ \\
12 & 4 & 74 & 18 & 0.054 & 29.2 & $2.469 \mathrm{E}+05$ & $4.568 \mathrm{E}+06$ & $19.5 \pm 10.0$ \\
13 & 9 & 91 & 16 & 0.099 & 40.5 & $6.250 \mathrm{E}+05$ & $6.319 \mathrm{E}+06$ & $35.6 \pm 12.5$ \\
14 & 0 & 7 & 30 & 0.000 & 1.7 & $0.000 \mathrm{E}+00$ & $2.593 \mathrm{E}+05$ & $0.0 \pm 0.0$ \\
15 & 0 & 1 & 30 & 0.000 & 0.2 & $0.000 \mathrm{E}+00$ & $3.704 \mathrm{E}+04$ & $0.0 \pm 0.0$ \\
16 & 0 & 3 & 18 & 0.000 & 1.2 & $0.000 \mathrm{E}+00$ & $1.852 \mathrm{E}+05$ & $0.0 \pm 0.0$ \\
17 & 2 & 9 & 9 & 0.222 & 7.1 & $2.469 \mathrm{E}+05$ & $1.111 \mathrm{E}+06$ & $79.7 \pm 62.3$ \\
18 & 1 & 12 & 24 & 0.083 & 3.6 & $4.630 \mathrm{E}+04$ & $5.556 \mathrm{E}+05$ & $30.0 \pm 31.2$ \\
19 & 0 & 2 & 25 & 0.000 & 0.6 & $0.000 \mathrm{E}+00$ & $8.889 \mathrm{E}+04$ & $0.0 \pm 1$ & 0.0 \\
20 & 1 & 5 & 25 & 0.200 & 1.4 & $4.444 \mathrm{E}+04$ & $2.222 \mathrm{E}+05$ & $71.8 \pm 78.6$ \\
21 & 2 & 27 & 20 & 0.074 & 9.6 & $1.111 \mathrm{E}+05$ & $1.500 \mathrm{E}+06$ & $26.7 \pm 19.6$ \\
22 & 1 & 11 & 30 & 0.091 & 2.6 & $3.704 \mathrm{E}+04$ & $4.074 \mathrm{E}+05$ & $32.7 \pm 34.2$ \\
23 & 0 & 14 & 25 & 0.000 & 4.0 & $0.000 \mathrm{E}+00$ & $6.222 \mathrm{E}+05$ & $0.0 \pm 0.0$ \\
24 & 0 & 11 & 16 & 0.000 & 4.9 & $0.000 \mathrm{E}+00$ & $7.639 \mathrm{E}+05$ & $0.0 \pm$ & 0.0 \\
25 & 0 & 3 & 15 & 0.000 & 1.4 & $0.000 \mathrm{E}+00$ & $2.222 \mathrm{E}+05$ & $0.0 \pm \pm 0.0$ \\
26 & 21 & 221 & 12 & 0.095 & 131.0 & $1.944 \mathrm{E}+06$ & $2.046 \mathrm{E}+07$ & $34.2 \pm \pm 7.8$ \\
\hline & 68 & 821 & & & 10.3 & $1.335 \mathrm{E}+05$ & $1.612 \mathrm{E}+06$ &
\end{tabular}

Area of basic unit $=.0000009 \mathrm{~cm} \cdot 2$

Chi Squared -18.246 with 25 degrees of freedom

$\mathrm{P}$ (chi squared $)=83.2 \%$

Correlation Coefficient $=0.972$

Variance of SQR(Ns) $=1.28$

Variance of SQR(Ni) $=11.51$

Age Dispersion $=0.009 \%$ (did not converge)

$\mathrm{N} s / \mathrm{Ni}=0.083 \pm 0.010$

Mean Ratio $=0.114 \pm 0.038$

Ages calculated using a zera of $352.7 \pm 5$ for SRM612 glass

Rho $D=2.046 E+06 \mathrm{~cm} \cdot 2 ; \quad \mathrm{ND}=4604$

POOLED AGE $=29.8 \pm 3.8 \mathrm{Ma}$

MEAN AGE $=40.9 \pm 13.8 \mathrm{Ma}$ 
89 POS 74A Gilead SS - Gilead CK.

IRRADIATION LU079

SLIDE NUMBER 12

COUNTED BY: P. O'Sullivan

\begin{tabular}{|c|c|c|c|c|c|c|c|c|}
\hline No. & Ns & $\mathrm{Ni}$ & $\mathrm{Na}$ & RATIO & $U(p p m)$ & RHOs & RHOi & F.T. AGE (Ma) \\
\hline 1 & 4 & 43 & 30 & 0.093 & 10.2 & $1.481 E+05$ & $1.593 E+06$ & $33.5 \pm 17.5$ \\
\hline 2 & 0 & 4 & 42 & 0.000 & 0.7 & $0.000 E+00$ & $1.058 E+05$ & $0.0 \pm$ \\
\hline 3 & 3 & 17 & 30 & 0.176 & 4.0 & $1.111 E+05$ & $6.296 \mathrm{E}+05$ & $63.4 \pm$ \\
\hline 4 & 0 & 8 & 20 & 0.000 & 2.8 & $0.000 \mathrm{E}+00$ & $4.444 E+05$ & $0.0 \pm$ \\
\hline 5 & 0 & 8 & 25 & 0.000 & 2.3 & $0.000 E+00$ & $3.556 E+05$ & $0.0 \pm$ \\
\hline 6 & 3 & 14 & 16 & 0.214 & 6.2 & $2.083 E+05$ & $9.722 \mathrm{E}+05$ & $76.9 \pm 48.9$ \\
\hline 7 & 0 & 1 & 21 & 0.000 & 0.3 & $0.000 E+00$ & $5.291 E+04$ & $0.0 \pm 0.0$ \\
\hline 8 & נ & 5 & 35 & 0.200 & 1.0 & $3.1758+04$ & $1.58 \pi E+05$ & $71.8 \pm 78.6$ \\
\hline 9 & 11 & 123 & 28 & 0.089 & 31.3 & $4.365 \mathrm{E}+05$ & $4.881 E+06$ & $32.2 \pm 10.2$ \\
\hline 10 & 0 & 10 & 35 & 0.000 & 2.0 & $0.000 \mathrm{E}+00$ & $3.175 E+05$ & $0.0 \pm \quad 0.0$ \\
\hline 11 & 0 & 29 & 25 & 0.000 & 8.3 & $0.000 \mathrm{E}+00$ & $1.289 E+06$ & $0.0 \pm$ \\
\hline 12 & 27 & 161 & 49 & 0.168 & 23.4 & $6.122 E+05$ & $3.651 E+06$ & $60.2 \pm 12.6$ \\
\hline 13 & 0 & 1 & 20 & 0.000 & 0.4 & $0.000 E+00$ & $5.556 \mathrm{E}+04$ & $0.0 \pm 0.0$ \\
\hline 14 & 1 & 7 & 35 & 0.143 & 1.4 & $3.175 \mathrm{E}+04$ & $2.222 E+05$ & $51.3 \pm 54.9$ \\
\hline 15 & 0 & 9 & 40 & 0.000 & 1.6 & $0.000 \mathrm{E}+\infty 0$ & $2.500 E+05$ & $0.0 \pm 0.0$ \\
\hline 16 & 0 & 1 & 24 & 0.000 & 0.3 & $0.000 E+00$ & $4.630 \mathrm{E}+04$ & $0.0 \pm$ \\
\hline 17 & 10 & 176 & 24 & 0.057 & 52.2 & $4.630 E+05$ & $8.148 E+06$ & $20.5 \pm$ \\
\hline 18 & 0 & 3 & 24 & 0.000 & 0.9 & $0.000 \mathrm{E}+\infty 0$ & $1.389 E+05$ & $0.0 \pm$ \\
\hline 19 & 3 & 38 & 24 & 0.079 & 11.3 & $1.389 E+05$ & $1.759 E+06$ & $28.4 \pm 17.1$ \\
\hline 20 & 1 & 7 & 36 & 0.143 & 1.4 & $3.086 \mathrm{E}+04$ & $2.160 \mathrm{E}+05$ & $51.3 \pm 54.9$ \\
\hline 21 & 1 & 21 & 60 & 0.048 & 2.5 & $1.852 E+04$ & $3.889 \mathrm{E}+05$ & $17.2 \pm 17.6$ \\
\hline 22 & 5 & 44 & 30 & 0.114 & 10.4 & $1.852 E+05$ & $1.630 E+06$ & $40.9 \pm 19.3$ \\
\hline 23 & 14 & 106 & 45 & 0.132 & 16.8 & $3.457 \mathrm{E}+05$ & $2.617 E+06$ & $47.5 \pm 13.5$ \\
\hline 24 & 38 & 497 & 42 & 0.076 & 84.2 & $1.005 E+06$ & $1.315 E+07$ & $27.5 \pm 4.7$ \\
\hline \multirow[t]{2}{*}{25} & 2 & 11 & 15 & 0.182 & 5.2 & $1,481 E+05$ & $8.148 E+05$ & $65.3 \pm 50.2$ \\
\hline & 124 & 1344 & & & 12.3 & $1.778 \mathrm{E}+05$ & $1.927 E+06$ & \\
\hline
\end{tabular}

Area of basic unit $=.0000009 \mathrm{~cm}-2$

Chi Squared $=25.809$ with 24 degrees of freedom

$\mathrm{P}($ chi squared $)=36.3 \%$

Correlation Coefficient $=0.935$

Variance of SQR(Ns) $=2.96$

Variance of SQR(Ni) $=25.07$

Age Dispersion $=26.980 \%$

$\mathrm{Ns} / \mathrm{Ni}=0.092 \pm 0.009$

Mean Ratio $=0.077 \pm 0.015$

Ages calculated using a zeta of $352.7 \pm 5$ for SRM612 glass

Rho $D=2.046 \mathrm{E}+06 \mathrm{~cm} \cdot 2 ; \quad \mathrm{ND}=4604$

POOLED AGE $=33.2 \pm 3.2 \mathrm{Ma}$

$M E A N$ AGE $=27.6 \pm 5.5 \mathrm{Ma}$ 
89 POS 76C Kemik - Gilend CK.

IRRADLATTON LU079

SLIDE NUMBER 13

COUNTED BY: P. O'Sullivan

\begin{tabular}{|c|c|c|c|c|c|c|c|c|}
\hline No. & Ns & $\mathrm{Ni}$ & $\mathrm{Na}$ & RATIO & $\mathrm{U}(\mathrm{ppm})$ & RHOS & RHOi & F.T. AGE (Ma) \\
\hline $\mathrm{l}$ & 10 & 59 & 24 & 0.169 & 17.5 & $4.630 \mathrm{E}+05$ & $2.731 \mathrm{E}+06$ & $60.9 \pm 20.9$ \\
\hline 2 & 0 & 5 & 20 & 0.000 & 1.8 & $0.000 \mathrm{E}+00$ & $2.778 E+05$ & $0.0 \pm 0.0$ \\
\hline 3 & 1 & 27 & 25 & 0.037 & 7.7 & $4.444 E+04$ & $1.200 E+06$ & $13.3 \pm 13.6$ \\
\hline 4 & 21 & 170 & 14 & 0.124 & 86.4 & $1.667 E+06$ & $1.349 E+07$ & $44.4 \pm 10.3$ \\
\hline 5 & 0 & 15 & 18 & 0.000 & 5.9 & $0.000 E+00$ & $9.259 E+05$ & $0.0 \pm 0.0$ \\
\hline 6 & 0 & 6 & 24 & 0.000 & 1.8 & $0.000 E+00$ & $2.778 E+05$ & $0.0 \pm$ \\
\hline 7 & 12 & 147 & 24 & 0.082 & 43.6 & $5.556 \mathrm{E}+05$ & $6.806 \varepsilon+06$ & $29.4 \pm$ \\
\hline 8 & 0 & 8 & 36 & 0.000 & 1.6 & $0.000 E+00$ & $2.469 E+05$ & $0.0 \pm$ \\
\hline 9 & 0 & 24 & 16 & 0.000 & 10.7 & $0.000 \mathrm{E}+00$ & $1.667 \mathrm{E}+06$ & $0.0 \pm$ \\
\hline 10 & 0 & 10 & 24 & 0.000 & 3.0 & $0.000 E+00$ & $4.630 E+05$ & $0.0 \pm$ \\
\hline 11 & 0 & 1 & 36 & 0.000 & 0.2 & $0.000 E+00$ & $3.086 E+04$ & $0.0 \pm$ \\
\hline 12 & 2 & 53 & 25 & 0.038 & 15.1 & $8.889 E+04$ & $2.356 \mathrm{E}+06$ & $13.6 \pm$ \\
\hline 13 & 9 & 58 & 24 & 0.155 & 17.2 & $4.167 \varepsilon+05$ & $2.685 E+06$ & $55.7 \pm 20.0$ \\
\hline 14 & 0 & 19 & 30 & 0.000 & 4.5 & $0.000 \mathrm{E}+\infty 0$ & $7.03 T E+05$ & $0.0 \pm 0.0$ \\
\hline 15 & 12 & 87 & 9 & 0.138 & 68.8 & $1.481 E+06$ & $1.074 E+07$ & $49.6 \pm 15.3$ \\
\hline 16 & 5 & 30 & 16 & 0.167 & 13.3 & $3.472 E+05$ & $2.083 E+06$ & $59.9 \pm 28.9$ \\
\hline 17 & 0 & 32 & 35 & 0.000 & 6.5 & $0.000 E+00$ & $1.016 \mathrm{E}+06$ & $0.0 \pm 0.0$ \\
\hline 18 & 9 & 105 & 35 & 0.086 & 21.3 & $2.857 \mathrm{E}+05$ & $3.333 E+06$ & $30.9 \pm 10.7$ \\
\hline 19 & 0 & 3 & 25 & 0.000 & 0.9 & $0.000 \mathrm{E}+00$ & $1.333 \mathrm{E}+05$ & $0.0 \pm 0.0$ \\
\hline 20 & 1 & 6 & 25 & 0.167 & 1.7 & $4.444 \mathrm{E}+04$ & $2.667 E+05$ & $59.9 \pm 64.7$ \\
\hline 21 & 7 & 33 & 18 & 0.212 & 13.0 & $4.321 E+05$ & $2.03 T E+06$ & $76.1 \pm 31.7$ \\
\hline 22 & 31 & 248 & 30 & 0.125 & 58.8 & $1.148 E+06$ & $9.185 E+06$ & $44.9 \pm 8.6$ \\
\hline 23 & 1 & 9 & 12 & 0.111 & 5.3 & $9.259 E+04$ & $8.333 E+05$ & $40.0 \pm 42.1$ \\
\hline 24 & 6 & 66 & 9 & 0.091 & 52.2 & $7.407 E+05$ & $8.148 \mathrm{E}+06$ & $32.7 \pm 14.0$ \\
\hline 25 & 5 & 31 & 28 & 0.161 & 7.9 & $1.984 \mathrm{E}+05$ & $1,230 \varepsilon+06$ & $57.9 \pm 27.9$ \\
\hline & 132 & 1252 & & & 15.3 & $2.520 \mathrm{E}+05$ & $2.390 E+06$ & \\
\hline
\end{tabular}

Area of basic unit $=.0000009 \mathrm{~cm}-2$

Chi Squared $=27.559$ with 24 degrees of freedom

$P($ chi squared $)=27.9 \%$

Correlation Coefficient $=0.955$

Variance of $S Q R(N s)=2.80$

Variance of SQR(Ni) $=14.26$

Age Dispersion $=13.634 \%$ (did not converge)

$\mathrm{Ns} / \mathrm{Ni}=0.105 \pm 0.010$

Mean Ratio $=0.074 \pm 0.015$

Ages calculated using a zeta of $352.7 \pm 5$ for SRM612 glass

Rho $D=2.046 \mathrm{E}+06 \mathrm{~cm}-2 ; \quad \mathrm{ND}=4604$

POOLED AGE $=37.9 \pm 3.6 \mathrm{Ma}$

MEAN AGE $=26.8 \pm 5.3 \mathrm{Ma}$ 
89 POS 77B Kemik - Gilead CK.

IRRADLATION LU079

SLIDE NUMBER 14

COUNTED BY: P. O'Sullivan

\begin{tabular}{|c|c|c|c|c|c|c|c|c|}
\hline No. & Ns & $\mathrm{Ni}$ & $\mathrm{Na}$ & RATTO & $U(p p m)$ & RHOs & RHOi & F.T. AGE (Ma) \\
\hline 1 & 3 & 49 & 30 & 0,061 & 11.6 & $1.111 E+05$ & $1.815 E+06$ & $22.1 \pm 13.1$ \\
\hline 2 & 1 & 19 & 28 & 0.053 & 4.8 & $3.968 \mathrm{E}+04$ & $7.540 \mathrm{E}+05$ & $19.0 \pm 19.5$ \\
\hline 3 & 7 & 94 & 25 & 0.074 & 26.7 & $3.111 E+05$ & $4.178 E+06$ & $26.8 \pm 10.5$ \\
\hline 4 & 1 & 11 & 40 & 0.091 & 2.0 & $2.778 \mathrm{E}+04$ & $3.056 \mathrm{E}+05$ & $32.7 \pm 34.2$ \\
\hline 5 & 1 & 18 & 25 & 0.056 & 5.1 & $4.444 E+04$ & $8.000 \mathrm{E}+05$ & $20.0 \pm 20.6$ \\
\hline 6 & 0 & 30 & 35 & 0.000 & 6.1 & $0.000 \mathrm{E}+00$ & $9.524 E+05$ & $0.0 \pm 0.0$ \\
\hline 7 & 7 & 82 & 24 & 0.085 & 24.3 & $3.241 E+05$ & $3.796 \mathrm{E}+06$ & $30.7 \pm 12.1$ \\
\hline 8 & 8 & 57 & 20 & 0.140 & 20.3 & 4.444E+05 & $3.167 \mathrm{E}+06$ & $50.4 \pm 19.1$ \\
\hline 9 & 32 & 170 & 24 & 0.188 & 50.4 & $1.481 E+06$ & $7.870 E+06$ & $67.6 \pm 13.1$ \\
\hline 10 & 0 & 37 & 30 & 0.000 & 8.8 & $0.000 E+00$ & $1.370 E+06$ & $0.0 \pm 0.0$ \\
\hline 11 & 1 & 26 & 32 & 0.038 & 5.8 & $3.472 E+04$ & $9.028 \mathrm{E}+05$ & $13.9 \pm 14.1$ \\
\hline 12 & 2 & 39 & 45 & 0.051 & 6.2 & $4.938 E+04$ & $9.630 \mathrm{E}+05$ & $18.5 \pm 13.4$ \\
\hline 13 & 0 & 24 & 20 & 0.000 & 8.5 & $0.000 \mathrm{E}+00$ & $1.333 E+06$ & $0.0 \pm 0.0$ \\
\hline 14 & 2 & 18 & 20 & 0.111 & 6.4 & $1.111 E+05$ & $1.000 E+06$ & $40.0 \pm 29.8$ \\
\hline 15 & 0 & 13 & 32 & 0.000 & 2.4 & $0.000 \mathrm{E}+00$ & $3.819 E+05$ & $0.0 \pm 0.0$ \\
\hline 16 & 8 & 53 & 12 & 0.151 & 31.4 & $7.407 E+05$ & $4.907 \mathrm{E}+06$ & $54.2 \pm 20.6$ \\
\hline 17 & 0 & 7 & 42 & 0.000 & 1.2 & $0.000 E+00$ & $1.852 E+05$ & $0.0 \pm 0.0$ \\
\hline 18 & 28 & 207 & 36 & 0.135 & 40.9 & $8.642 E+05$ & $6.389 E+06$ & $48.6 \pm 9.8$ \\
\hline 19 & 0 & 27 & 24 & 0.000 & 8.0 & $0.000 \mathrm{E}+00$ & $1.250 E+06$ & $0.0 \pm 0.0$ \\
\hline 20 & 15 & 112 & 30 & 0.134 & 26.6 & $5.556 \mathrm{E}+05$ & $4.148 E+06$ & $48.1 \pm 13.3$ \\
\hline 21 & 7 & 71 & 16 & 0.099 & 31.6 & $4.861 E+05$ & $4.931 E+\infty 6$ & $35.5 \pm 14.1$ \\
\hline 22 & 1 & 7 & 25 & 0.143 & 2.0 & $4.444 E+04$ & $3.111 E+05$ & $51.3 \pm 54.9$ \\
\hline 23 & 4 & 39 & 24 & 0.103 & 11.6 & $1.852 E+05$ & $1.806 \mathrm{E}+06$ & $36.9 \pm 19.4$ \\
\hline 24 & 1 & 15 & 30 & 0.067 & 3.6 & $3.704 \mathrm{E}+04$ & $5.556 \mathrm{E}+05$ & $24.0 \pm 24.8$ \\
\hline \multirow[t]{2}{*}{25} & 2 & 19 & 36 & 0.105 & 3.8 & $6.173 E+04$ & $5.864 E+05$ & $37.9 \pm 28.2$ \\
\hline & 13 & 1242 & & & 12.5 & $2.065 E+05$ & $3.957 \mathrm{E}+06$ & \\
\hline
\end{tabular}

Area of basic unit $=.0000009 \mathrm{~cm}-2$

Chi Squared $=32669$ with 24 degrees of freedom

$\mathrm{P}($ chi squared $)=11.1 \%$

Correlation Coefficiens $=0.950$

Variance of SQR(Ns) $=246$

Variance of SQR(Ni) $=9.48$

Age Dispersion $=39.981 \%$

$\mathrm{N} s \mathrm{Ni}=0.105 \pm 0.010$

Mean Racio $\approx 0.075 \pm 0.011$

Ages calculated using a zeta of $352.7 \pm 5$ for SRM612 glass

Rho $D=2.046 \mathrm{E}+06 \mathrm{~cm}-2 ; \quad \mathrm{ND}=4604$

POOLED AGE $=37.9 \pm 3.6 \mathrm{Ma}$

MEAN AGE $=27.2 \pm 4.1 \mathrm{Ma}$ 
89 POS 79B Hue Shale - Gilcad Ck.

IRRADLATION LU079

SLIDE NUMBER 15

COUNTED BY: P. O'Sullivan

\begin{tabular}{cllllccccc}
\hline No. & Ns & Ni & Na & RATTO & U (ppm) & RHOs & RHOi & F.T. AGE (Ma) \\
\hline 1 & 3 & 28 & 30 & 0.107 & 6.6 & $1.111 \mathrm{E}+05$ & $1.037 \mathrm{E}+06$ & $38.5 \pm 23.4$ \\
2 & 12 & 82 & 50 & 0.146 & 11.7 & $2.667 \mathrm{E}+05$ & $1.822 \mathrm{E}+06$ & $52.6 \pm 16.3$ \\
3 & 3 & 30 & 35 & 0.100 & 6.1 & $9.524 \mathrm{E}+04$ & $9.524 \mathrm{E}+05$ & $36.0 \pm 21.8$ \\
4 & 10 & 56 & 24 & 0.179 & 16.6 & $4.630 \mathrm{E}+05$ & $2.593 \mathrm{E}+06$ & $64 . \mathrm{I} \pm 22.0$ \\
5 & 16 & 147 & 40 & 0.109 & 26.1 & $4.444 \mathrm{E}+05$ & $4.083 \mathrm{E}+06$ & $39.2 \pm 10.3$ \\
6 & 7 & 71 & 60 & 0.099 & 8.4 & $1.296 \mathrm{E}+05$ & $1.315 \mathrm{E}+06$ & $35.5 \pm 14.1$ \\
7 & 13 & 137 & 40 & 0.095 & 24.4 & $3.611 \mathrm{E}+05$ & $3.806 \mathrm{E}+06$ & $34.1 \pm \pm .9$ \\
8 & 1 & 58 & 45 & 0.017 & 9.2 & $2.469 \mathrm{E}+04$ & $1.432 \mathrm{E}+06$ & $6.2 \pm 6.3$ \\
9 & 6 & 104 & 50 & 0.058 & 14.8 & $1.333 \mathrm{E}+05$ & $2.311 \mathrm{E}+06$ & $20.8 \pm 8.7$ \\
10 & 7 & 46 & 32 & 0.152 & 10.2 & $2.431 \mathrm{E}+05$ & $1.597 \mathrm{E}+06$ & $54.7 \pm 22.2$ \\
11 & 5 & 66 & 50 & 0.076 & 9.4 & $1.111 \mathrm{E}+05$ & $1.467 \mathrm{E}+06$ & $27.3 \pm 12.7$ \\
12 & 4 & 36 & 24 & 0.111 & 10.7 & $1.852 \mathrm{E}+05$ & $1.667 \mathrm{E}+06$ & $40.0 \pm 21.1$ \\
13 & 6 & 69 & 48 & 0.087 & 10.2 & $1.389 \mathrm{E}+05$ & $1.597 \mathrm{E}+05$ & $31.3 \pm 13.3$ \\
14 & 7 & 69 & 32 & 0.101 & 15.3 & $2.431 \mathrm{E}+05$ & $2.396 \mathrm{E}+06$ & $36.5 \pm 14.5$ \\
15 & 10 & 79 & 35 & 0.127 & 16.1 & $3.175 \mathrm{E}+05$ & $2.508 \mathrm{E}+06$ & $45.5 \pm 15.3$ \\
16 & 2 & 32 & 48 & 0.062 & 4.7 & $4.630 \mathrm{E}+04$ & $7.407 \mathrm{E}+05$ & $22.5 \pm 16.4$ \\
17 & 4 & 32 & 25 & 0.125 & 9.1 & $1.778 \mathrm{E}+05$ & $1.422 \mathrm{E}+06$ & $44.9 \pm 23.9$ \\
18 & 5 & 39 & 24 & 0.128 & 11.6 & $2.315 \mathrm{E}+05$ & $1.806 \mathrm{E}+06$ & $46.1 \pm 21.9$ \\
19 & 2 & 25 & 25 & 0.080 & 7.1 & $8.889 \mathrm{E}+04$ & $1.111 \mathrm{E}+06$ & $28.8 \pm 21.2$ \\
20 & 0 & 19 & 16 & 0.000 & 8.4 & $0.000 \mathrm{E}+00$ & $1.319 \mathrm{E}+06$ & $0.0 \pm 0.0$ \\
21 & 0 & 51 & 28 & 0.000 & 13.0 & $0.000 \mathrm{E}+00$ & $2.024 \mathrm{E}+06$ & $0.0 \pm 0.0$ \\
22 & 7 & 68 & 25 & 0.103 & 19.4 & $3.111 \mathrm{E}+05$ & $3.022 \mathrm{E}+06$ & $37.0 \pm 14.7$ \\
23 & 5 & 32 & 20 & 0.156 & 11.4 & $2.778 \mathrm{E}+05$ & $1.778 \mathrm{E}+06$ & $56.1 \pm 27.0$ \\
24 & 0 & 21 & 35 & 0.000 & 4.3 & $0.000 \mathrm{E}+00$ & $6.667 \mathrm{E}+05$ & $0.0 \pm 0.0$ \\
25 & 1 & 23 & 15 & 0.043 & 10.9 & $7.407 \mathrm{E}+04$ & $1.704 \mathrm{E}+06$ & $15.7 \pm 16.0$ \\
\hline
\end{tabular}

Area of basic unit $=.0000009 \mathrm{~cm}-2$

Chi Squared $=24.659$ with 24 degrees of freedom

$P($ chi squared $)=42.4 \%$

Correlation Coefficient $=0.832$

Variance of SQR(Ns) $=1.18$

Variance of SQR(Ni) $=4.49$

Age Dispersion $=6.259 \%$ (did not converge $)$

$\mathrm{Ns} / \mathrm{Ni}=0.096 \pm 0.009$

Mean Ratio $=0.090 \pm 0.010$

Ages calculated using a zetr of $352.7 \pm 5$ for SRM612 glass

Rho $\mathrm{D}=2.046 \mathrm{E}+06 \mathrm{~cm}-2 ; \quad \mathrm{ND}=4604$

POOLED AGE $=34.5 \pm 3.2 \mathrm{Ma}$

MEAN AGE $=32.6 \pm 3.6 \mathrm{Ma}$ 
89 POS 818 Canning Fm. - Gilead CK

IRRADLATION LU080

SLIDE NUMBER 1

COUNTED BY: P. O'Sullivan

\begin{tabular}{lllllclccc}
\hline No. & Ns & Ni & Na & RATIO & \multicolumn{2}{c}{ U (Dpm) } & RHOs & RHOi & F.T. AGE (Ma) \\
\hline 1 & 6 & 42 & 40 & 0.143 & 6.9 & $1.667 \mathrm{E}+05$ & $1.167 \mathrm{E}+06$ & $55.3 \pm 24.2$ \\
2 & 1 & 16 & 50 & 0.062 & 2.1 & $2.222 \mathrm{E}+04$ & $3.556 \mathrm{E}+05$ & $24.3 \pm$ & 25.0 \\
3 & 17 & 174 & 35 & 0.098 & 32.8 & $5.397 \mathrm{E}+05$ & $5.524 \mathrm{E}+06$ & $37.9 \pm$ & 9.7 \\
4 & 4 & 22 & 50 & 0.182 & 2.9 & $8.889 \mathrm{E}+04$ & $4.889 \mathrm{E}+05$ & $70.3 \pm 38.3$ \\
5 & 3 & 27 & 40 & 0.111 & 4.5 & $8.333 \mathrm{E}+04$ & $7.500 \mathrm{E}+05$ & $43.1 \pm 26.2$ \\
6 & 15 & 143 & 49 & 0.105 & 19.3 & $3.401 \mathrm{E}+05$ & $3.243 \mathrm{E}+06$ & $40.7 \pm 11.1$ \\
7 & 22 & 224 & 36 & 0.098 & 41.1 & $6.790 \mathrm{E}+05$ & $6.914 \mathrm{E}+06$ & $38.1 \pm$ & 8.5 \\
8 & 40 & 207 & 25 & 0.193 & 54.6 & $1.778 \mathrm{E}+06$ & $9.200 \mathrm{E}+06$ & $74.7 \pm 13.0$ \\
9 & 17 & 73 & 70 & 0.233 & 6.9 & $2.698 \mathrm{E}+05$ & $1.159 \mathrm{E}+06$ & $90.0 \pm 24.3$ \\
10 & 2 & 11 & 35 & 0.182 & 2.1 & $6.349 \mathrm{E}+04$ & $3.492 \mathrm{E}+05$ & $70.3 \pm 54.1$ \\
11 & 16 & 163 & 80 & 0.098 & 13.4 & $2.222 \mathrm{E}+05$ & $2.264 \mathrm{E}+06$ & $38.1 \pm 10.0$ \\
12 & 47 & 493 & 48 & 0.095 & 67.8 & $1.088 \mathrm{E}+06$ & $1.141 \mathrm{E}+07$ & $37.0 \pm 5.7$ \\
13 & 23 & 157 & 35 & 0.146 & 29.6 & $7.302 \mathrm{E}+05$ & $4.984 \mathrm{E}+05$ & $56.7 \pm 12.7$ \\
14 & 5 & 44 & 56 & 0.114 & 5.2 & $9.921 \mathrm{E}+04$ & $8.730 \mathrm{E}+05$ & $44.1 \pm 20.8$ \\
15 & 6 & 32 & 54 & 0.188 & 3.9 & $1.235 \mathrm{E}+05$ & $6.584 \mathrm{E}+05$ & $72.5 \pm 32.3$ \\
16 & 51 & 499 & 36 & 0.102 & 91.5 & $1.574 \mathrm{E}+06$ & $1.540 \mathrm{E}+07$ & $39.6 \pm$ & 5.9 \\
17 & 30 & 281 & 60 & 0.107 & 30.9 & $5.556 \mathrm{E}+05$ & $5.204 \mathrm{E}+06$ & $41.4 \pm 8.0$ \\
18 & 2 & 14 & 48 & 0.143 & 1.9 & $4.630 \mathrm{E}+04$ & $3.241 \mathrm{E}+05$ & $55.3 \pm 41.8$ \\
19 & 7 & 43 & 60 & 0.163 & 4.7 & $1.296 \mathrm{E}+05$ & $7.963 \mathrm{E}+05$ & $63.0 \pm 25.7$ \\
20 & 21 & 256 & 50 & 0.082 & 33.8 & $4.667 \mathrm{E}+05$ & $5.689 \mathrm{E}+06$ & $31.8 \pm 7.3$ \\
21 & 29 & 220 & 56 & 0.132 & 25.9 & $5.754 \mathrm{E}+05$ & $4.365 \mathrm{E}+06$ & $51.1 \pm 10.1$ \\
22 & 0 & 26 & 40 & 0.000 & 4.3 & $0.000 \mathrm{E}+00$ & $7.222 \mathrm{E}+05$ & $0.0 \pm$ & 0.0 \\
23 & 9 & 99 & 64 & 0.091 & 10.2 & $1.562 \mathrm{E}+05$ & $1.719 \mathrm{E}+06$ & $35.3 \pm 12.3$ \\
24 & 1 & 9 & 50 & 0.111 & 1.2 & $2.222 \mathrm{E}+04$ & $2.000 \mathrm{E}+05$ & $43.1 \pm 45.4$ \\
25 & 2 & 9 & 40 & 0.222 & 1.5 & $5.556 \mathrm{E}+04$ & $2.500 \mathrm{E}+05$ & $85.9 \pm 67.2$ \\
\hline & 376 & 3284 & & & 18.0 & $3.461 \mathrm{E}+05$ & $3.023 \mathrm{E}+06$ & &
\end{tabular}

Area of basic unit $=.0000009 \mathrm{~cm}-2$

Chi Squared $=32.020$ with 24 degrees of freedom

$\mathrm{P}($ chi squared $)=12.6 \%$

Correlation Coefficient $=0.947$

Variance of SQR(Ns) $=3.87$

Variance of SQR $(\mathrm{Ni})=34.49$

Age Dispersion $=16.534 \%$

$\mathrm{N} s / \mathrm{Ni}=0.114 \pm 0.006$

Mean Ratio $=0.128 \pm 0.010$

Ages calculated using a zeta of $352.7 \pm 5$ for SRM612 glass

Rho $D=2.206 \mathrm{E}+06 \mathrm{~cm}-2 ; \quad \mathrm{ND}=4963$

POOLED AGE $=44.4 \pm 2.6 \mathrm{Ma}$

MEAN AGE $=49.6 \pm 4.2 \mathrm{Ma}$ 